\title{
Recommendations: Titles We Beg You to Read or Avoid
}

By everyone in the course

\section{Books (for many ages) we recommend reading}

the Adventures of Captain Underpants series, Dav Pilkey

the Animorphs series, K.A. Applegate \& all her ghostwriters

anything by Daniel Manus Pinkwater

anything by Russell Hoban

anything by Tamora Pierce

the Artemis Fowl series, Eoin Colfer

the Calvin and Hobbes collections, Bill Watterson

the Deltora Quest series, Emily Rodda

Forever Evil, Geoff Johns \& David Finch

Graceling, Kristin Cashore

Green Grass, Running Water, Thomas King

the Harry Potter series, J.K. Rowling

The Henna Artist, Alka Joshi

Home Fire, Kamila Shamsie

the Inkheart series, Cornelia Funke

Jade City, Fonda Lee

Kitchen Princess series, Miyuki Kobayashi \& Natsumi Andō

the Magic Treebouse series, Mary Pope Osborne

the Mortal Instruments series, Cassandra Clare

Olivia Kidney, Ellen Potter

the On the Run series, Gordon Korman

Oryx and Crake, Margaret Atwood

The Perks of Being a Wallflower, Stephen Chbosky

Pride and Prejudice, Jane Austen

the Ramona series, Beverly Cleary

The Rule of Three, Eric Walters 
Sailor Moon, Naoko Takeuchi

The Sandman, Neil Gaiman \& various artists

A Series of Unfortunate Events series, Lemony Snicket

Strange Angels series, Lili St. Crow

Sundancer, Shelley Peterson

various series, Jo Nesbø

When You Reach Me, Rebecca Stead

Wither, Lauren DeStefano

\section{Books (for many ages) we recommend avoiding}

the Animorphs series, K.A. Applegate \& all her ghostwriters

anything by John Green

anything by Shakespeare

the Charlie Bone series, Jenny Nimmo

the Harry Potter series, J.K. Rowling

Hot Pterodactyl Boyfriend, Alan Cumyn

(c) $(\$)$ This work is licensed under a Creative Commons Attribution-

EY No ND NonCommercial-NoDerivatives 4.0 International License.

(C) Nicky Didicher et al., 2021

ENGL487W - Summer 2021 